\title{
Responsible Leadership, Stakeholder Engagement, and the Emergence of Social Capital
}

\begin{abstract}
I argue in this article that responsible leadership (Maak and Pless, 2006) contributes to building social capital and ultimately to both a sustainable business and the common good. I show, first, that responsible leadership in a global stakeholder society is a relational and inherently moral phenomenon that cannot be captured in traditional dyadic leader-follower relationships (e.g., to subordinates) or by simply focusing on questions of leadership effectiveness. Business leaders have to deal with moral complexity resulting from a multitude of stakeholder claims and have to build enduring and mutually beneficial relationships with all relevant stakeholders. I contend, second, that in doing so leaders bundle the energy of different constituencies and enable social capital building. Social capital can be understood as actual or potential resources inherent to more or less institutionalized relationships of mutual recognition (Bourdieu 1980). By drawing on network analysis I suggest, third, that responsible leaders weave durable relational structures and ultimately networks of relationships which are rich in ties to otherwise unconnected individuals or groups. Against this background I argue, fourth, that responsible leadership may result in the creation of value networks (Lord and Brown,
\end{abstract}

Dr. Thomas Maak is a Research Director at the Institute for Business Ethics and a Reader in Corporate Responsibility at the University of St. Gallen (Switzerland) and Visiting Senior Research Fellow at INSEAD, France, where he codirects a research stream on "Developing responsible leadership for sustainable business" within the PwC-INSEAD initiative on high-performing organizations. He recevied his Ph.D. in Business Ethics, Summa Cum Laude, from the University of St. Gallen and held visiting appointments at Columbia University and Georgetown University. Currently, he is a member of the executive committee of the European Business Ethics Network EBEN. Among his many publication is the recent "Responsible Leadership," published by Routledge in 2006.
2001) of multiple stakeholders, which enhance social capital and thereby contribute to both a sustainable business and the common good.

KEY WORDS: responsible leadership, social capital, stakeholder relationships, leadership ethics

\section{The quest for responsible leadership}

One of the key lessons to be learnt from Enron and other corporate scandals in recent years is arguably that it takes responsible leadership and responsible leaders to build and sustain a business that is of benefit to multiple stakeholders (and not just to a few risk-seeking individuals). The corporate scandals have triggered a broad discussion on the role of business in society, that is to say, on its legitimacy, obligations, and responsibilities. As a result, businesses and their leaders are increasingly held accountable for what they do - and fail to do by multiple stakeholders and society at large. Given the power of large corporations in particular, stakeholders e.g., expect that business leaders take a more active role and thus acknowledge their coresponsibility vis-à-vis the pressing problems in the world such as protecting and promoting human rights, ensuring sustainability, contributing to poverty alleviation and the fight against diseases like HIV/AIDS. There is agreement in both business and society that multinational corporations and their leaders have both power and potential for contributing to the betterment of the world.

However, this endeavor requires responsible global leaders - leaders with responsible mindsets 
who care for the needs of others and act as global and responsible citizens. Yet, with few exceptions (Ciulla, 1998; Doh and Stumpf, 2005; Maak and Pless, 2006a) we still have little knowledge about responsible leadership and even less about how to develop responsibility in leaders to prepare them for the challenges of a global and interconnected stakeholder society. Still, recent developments and initiatives such as the multi-stakeholder forum UN Global Compact (which as of 2006 has more than 1,000 corporate members), the Global Business Coalition on HIV/AIDS, the Business Leader's Initiative on Human Rights (BLIHR), the World Business Council for Sustainable Development's (WBCSD) "Tomorrow's Leaders Group," or the European Foundation of Management Development's (EFMD) "Call for Responsible Global Leadership" are clear indicators that more and more organizations are actively seeking ways to promote responsible leadership in business and that multinational corporations are willing to accept their responsibilities as businesses in society. Among the key questions they are being asked, and ask themselves, are: How can business leadership become more responsible? How can businesses contribute to tackling some of the world's most pressing problems? What are today's and tomorrow's challenges of leading responsibly in a global stakeholder society?

In answering these questions, as I will argue in what follows, business leaders have to deal with moral complexity resulting from a multitude of stakeholder claims and have to build enduring and mutually beneficial relationships with all relevant stakeholders. To succeed, responsible leaders bundle the energy of different constituencies and enable the creation of value networks (Lord and Brown, 2001: 141) of multiple stakeholders, which enhance social capital and thereby contribute to both a sustainable business and the common good.

\section{Challenges of responsible leadership in a stakeholder society}

There is widespread agreement that the stakeholder framework has proved useful in the analysis of the strategic and normative challenges organizations face, and that good stakeholder relationships are key to organizational viability and business success
(Donaldson and Preston, 1995; Freeman, 1984, 1994; Post et al., 2002; Svendsen, 1998; Wheeler and Sillanpää, 1997). Still, there are both theoretical and practical challenges with respect to stakeholder salience in general (Jones et al., 2007; Mitchell et al., 1997), and evaluating and balancing the various and often conflicting claims of multiple stakeholders (employees, clients, shareholder, suppliers, NGOs, communities, government, nature, future generations, etc.) in particular. It calls for pro-active engagement (Burke, 2005) and requires leaders to enable inclusive stakeholder engagement and dialogue, to facilitate a legitimating discourse (Habermas, 1981, 1991; Apel, 1988) and to help balance diverse claims ensuring ethically sound decisionmaking. Thus, organizations and their leaders face the challenge of weaving a web of sustainable relationships, complex as it may be, navigating in it, and engaging a multitude of stakeholders in a dialog (across differences) to create resonance (Boyatzis and McKee, 2005), trust (Nooteboom, 2002), and ultimately stakeholder social capital.

In an interconnected and multicultural global stakeholder society moral dilemmas are almost inevitable. How can one adhere to fundamental moral principles while still respecting cultural differences and taking into consideration different developmental standards? (Donaldson, 1996; DeGeorge, 1993) What needs to be done to secure "uncompromising integrity" (Moorthy et al., 1998), while leaving leeway for discretion in matters such as gifts or application of corporate values? What is required to secure supply-chain integrity? Leadership failure in any of these or any related areas may create significant reputational damage, leading to consumer boycotts or, even worse, to the loss of the license to operate. Communication technologies and NGO activities have led to a historically unique level of transparency in matters of (global) business ethics. Against this backdrop leaders have to make sure that both individual and organizational actions are ethically sound.

Another equally demanding challenge is inherent to the art of leading as such: responsible leadership in business needs leadership ethics. This might seem to be stating the obvious. However, if we look at the many scandals and examples of "bad leadership" (Kellerman, 2004) and ethical failures in leadership (Price, 2005) in recent years, and the lack of theories on responsible leadership, then it is not surprising to 
see leaders struggling with questions that make up the very core of leadership. Ethics is at "the heart of leadership" (Ciulla, 1998), but a theory of responsible leadership has yet to be developed (see Maak and Pless, 2006a).

Furthermore, balancing different stakeholder claims, including those of the natural environment, future generations, and less privileged groups "at the bottom of the pyramid" (Prahalad, 2005) creates social, ecological and humanitarian challenges. Against this backdrop leaders are confronted with the challenge of business sustainability. While many corporations have adopted a "triple-bottom-line" approach (Elkington, 1998) and have started to integrate social and environmental considerations into their values creation, few have yet taken on humanitarian challenges - poverty, hunger, disease, and injustice - which prevent large parts of the human community from participating in the global economy, let alone benefiting from it. The actual challenge at hand is twofold - on the one hand to exercise active global corporate citizenship, fighting the above problems, and live up to the responsibility that comes with the increased power that especially multinational corporations nowadays have; on the other hand to create a "more inclusive brand of capitalism, one that incorporates previously excluded voices, concerns, and interests" (Hart, 2005: xli). In other words, the sustainability of any business ultimately comes down to the sustainability of the business system. Whether it is called "compassionate capitalism" (Benioff and Southwick, 2004), "moral capitalism" (Young, 2003), or "inclusive capitalism" (Hart, 2005), is a matter of taste and largely beside the point. What matters, though, is that leaders make sure that their organizations adopt a truly inclusive and ethically sound way of creating value for all legitimate stakeholders, including previously excluded ones and future generations.

\section{Responsible leadership and social capital: An emerging research vista}

Obviously, the leadership challenges in a global stakeholder society are manifold. Moreover, in this context the purpose of leadership can be understood as building and cultivating trustful sustainable relationships with stakeholders inside and outside the organization to achieve mutually shared objectives based on a vision of business as a force of good for the many, and not just a few (shareholders, managers) (Maak and Pless, 2006b: 103). In fact, I argue against this background, that leaders need to build, and rely on, social capital, i.e., social structures and resources both, internal and external to the organization, which allow us to facilitate responsible action and which are inherent to more or less institutionalized relationships of mutual recognition (Coleman, 1988; Bourdieu, 1980). Key to responsible leadership is thus the ability to enable and broker sustainable, mutual beneficial relationships with stakeholders, to create stakeholder goodwill and trust and ultimately a trusted business in society - that is, one of multi-stakeholder benefit.

Yet, so far neither the role of leadership in building social capital, nor its relevance for sustainable stakeholder relationships has been researched in more detail. Hitt and Ireland (2002) have argued that managing social capital is the "essence of strategic leadership" and Ballet (2005) tried to link social capital and the stakeholder concept. In research on social networks Galaskiewicz and Shatin (1981) have shown that in times of uncertainty, leaders of neighborhood organizations would build cooperative relations, using their personal connections; while Balkundi and Kilduff (2005) have recently outlined a "network approach to leadership," highlighting "the ties that lead". More explicitly, Andriof and Waddock (2002: 27) contend that "in an era of networked stakeholder relationships, understanding social capital is essential to learning how to construct and maintain corporation-stakeholder connections." And Burt (1997: 339), a leading proponent of social capital theory, remarks: "Knowing who, when, and how to coordinate is a function of the manager's network of contacts within and beyond the firm." However, Adler and Kwon (2002: 36) have argued that mapping all social capital ties that are relevant to the various tasks the organization faces poses a considerable challenge: after all, "it is far easier to map a small number of ego networks than to generate an intelligible, whole-network map of a large, complex organization." They therefore express their hope that future research will develop ways to tackle this task.

As I will argue below, it is a key quality of responsible leaders to act as weaver and broker of social capital. Thus, research on responsible leadership and its role in building social capital may contribute 
significantly to creating that whole-network map of complex relationships of an organization and its stakeholders. Moreover, it can shed light on the dynamics of hierarchy and non-hierarchy in leaderstakeholder relations. On the one hand, Adler and Kwon (2002) have argued that hierarchy can be a facilitator of social capital, as leaders have both power and influence to shape the structure of social relations. On the other, however, relations to most external stakeholders are non-hierarchical: a leader engages herself among equals; thus neither position nor status but the ability to build and sustain trustful relations to diverse stakeholders becomes the key facilitator in building stakeholder social capital. This "zooming in and out" (Ibarra et al., 2005) of different levels of analysis (individuals and social structure) and leadernetwork configurations promises to be a very fruitful approach. Our attempt here is to highlight its importance in the context of responsible leadership.

Finally, we can also gather support from emerging research on leadership complexity. Hooijberg et al. (1997: 389) e.g., contend that "most leaders interact almost simultaneously with a variety of stakeholders, in multiple and rapidly changing settings. For that reason, we must not only concern ourselves with a leader's behavioral repertoire, but also address how such leaders achieve effective functioning across a variety of situations." Of particular concern, as I will argue, is the leader's role in fostering the emergence of stakeholder social capital.

Before we can explore in more detail the role of leadership in the creation of social capital, however, we need to turn to the concept itself, which has received widespread attention for the past two decades, first in community studies and since the mid-90s in organization studies. The key argument might be summarized as follows: social capital is as essential for the well-being of communities as it is for individual and organizational success.

\section{Social capital}

The term social capital refers to features that enable people to act collectively (Woolcock and Narayan, 2000): the networks, relationships, norms, trust and thus the goodwill inherent in social relations (Adler and Kwon, 2002; Putnam, 1993). The concept has been, and still is, increasingly popular across the social sciences. In fact, the past two decades have seen a rapidly growing body of research (see Adler and Kwon, 2002; Portes, 1998 and Woolcock, 1998, for overviews). Social capital is, however, not a new concept. As early as 1916, we find a reference in the writings of Lydia Hanifan (1916), then a school superintendent, who reflected on important social resources like goodwill, fellowship and sympathy and remarked that if an individual comes "into contact with his neighbor, and they with other neighbors, there will be an accumulation of social capital..." (130) Much later the term appeared in community studies (Jacobs, 1965) and a study on racial income equality (Loury, 1977). The latter paved the way for the influential work of James Coleman (1988) on "social capital in the creation of human capital", although the first contemporary analysis of social capital was done by Pierre Bourdieu (1980) who defined it as "the aggregate of actual or potential resources which are linked to possession of a durable network of more or less institutionalized relationships of mutual acquaintance or recognition" (cited in Portes, 1998). Bourdieu's analysis focuses on the benefits of sociability and argues that "the profits which accrue from membership in a group are the basis of the solidarity which makes them possible" (Bourdieu, 1985: 249). He is explicit that social networks are constructed through investment strategies in group relations of mutual advantage.

It comes as no surprise, then, that the concept has received widespread attention from economists as well as organizational theorists who want to better understand the resource that is key to, and can be mobilized to facilitate social action. (See Adler and Kwon, 2002, for some arenas of concern). Here, the notion of social capital is considered in straightforward terms as an "investment in social relations with expected returns in the marketplace" (Lin, 2001: 19). Linked with social network theory (Borgatti and Foster, 2003; Brass et al., 1998; Carroll and Teo, 1996; Gargiulo and Benassi, 2000; Ibarra et al., 2005; Maurer and Ebers, 2006; Podolny and Baron, 1997; Ring and Van de Ven, 1994; Walker et al., 1997) and based on the insight that economic action is embedded in social structure (Granovetter, 1985; Uzzi, 1997), social capital has become an "umbrella concept," as Adler and Kwon (2002) argue, citing 
Hirsch and Levin (1999), spanning from individuallevel analysis to community-level analysis.

The latter was popularized by Robert Putnam's influential studies on community life in Italy and the demise of community life and associations in the United States, which Putnam entitled the "bowling alone" phenomenon (2000). He defines social capital as "features of social organization, such as networks, norms, trust, that facilitate coordination and cooperation for mutual benefit" (1993). His definition is echoed in a popular conceptualization by Cohen and Prusak (2001: 4), who argue that "social capital consists of the stock of active connections among people: the trust, mutual understanding, and shared values and behaviors that bind the members of human networks and communities and make cooperative action possible." In contrast, Nahapiet and Ghoshal (1998: 243) adopt a resource-based view that also includes potential resources, and define social capital "as the sum of the actual and potential resources embedded within, available through, and derived from the network of relationships possessed by an individual or social unit." Adler and Kwon (2002: 23), who also stress both the individual and group dimension of social capital, emphasizes the quality of these resources as beneficial assets: "Social capital is the goodwill available to individuals or groups. Its source lies in the structure and content of the actor's social relations. Its effects flow from the information, influence, and solidarity it makes available to the actor."

What most authors seem to agree on is that there is, depending on its configuration, potential value in the content of social network ties. Yet, due to the complexity of the fabric of social relations and the varying motivations to access the resources in question, we find multiple levels of analysis, content or structural approaches, and normative or instrumental takes on social capital. Thus, hidden under the 'umbrella term', we encounter a rather multi-dimensional concept: definitions vary depending on whether the research focus is on the individual actor or a group (i.e. organization), or both; on the structure of social ties, its configuration and adaptability; on the content of these ties, that is the actual sources like norms of reciprocity, mutual recognition, or shared cognition about what is socially desirable; and on either the instrumental or normative motivation to use social capital: is it meant to benefit the individual or the group and community?
In more general terms, using Gittell and Vidal's (1998) distinction, most conceptual attempts can be grouped into "bonding" and "bridging" social capital. The bonding views (e.g., Coleman, 1988; Putnam, 1993, 2000) emphasize the social capital inherent in the social structure, the shared cognition and norms and values of a particular group or collectivity; these views focus on actual or potential internal resources. In contrast, the bridging views (e.g., Bourdieu, 1985; Bourdieu and Wacquant, 1992; Burt, 1992, 1997, 2005; and most network theorists) stress the benefits of tying into external resources inherent in the nodes and relations of a social network. In other words, while bonding views focus on the benefits of 'social glue' and thus the internal relations of a community or an organization, bridging views try to explain how the activation of existing or potential external social relations to individual or collective actors may facilitate successful action. However, there are also synergetic or integrative views (e.g., Adler and Kwon, 2002; Nahapiet and Ghoshal, 1998; Woolcock, 1998, 2000) which suggest that with respect to practical action a balanced approach is advisable. Adler and Kwon e.g. argue "that management should pay heed to both. Investments in building the external, bridging social capital of individuals (...), or of the firm as a whole need to be balanced by investments in internal, bonding social capital within units, within the firm, and within interfirm networks." (2002: 35) For the purpose of explaining the role of leadership in building stakeholder social capital we adopt an integrative perspective. Moreover, given the complexity and challenges of leading responsibly - that is ethically sound leadership embedded in a network of internal and external stakeholders who claim different stakes at different times based on potentially conflicting values - and given the diversity and multiplexity of social ties and relationships, we must adopt a balanced, integrative view.

Against this backdrop, I use the following working definition: Social capital consists of social structures and resources which are inherent to more or less institutionalized relationships of mutual recognition, both internal and external to the organization, which allow facilitating mutually beneficial, responsible action. The emphasis on mutual recognition and beneficence indicates that access and use of social capital is not geared at just benefiting the individual leader; it is not about the individual 
benefits resulting from becoming more and better connected. Rather, in establishing trustful relationships with multiple stakeholders, in building bridges and connecting (to) stakeholders, and in engaging them to realize a meaningful business vision, the leader is central in enabling stakeholder social capital to further the common good. Before I discuss this in more detail, however, I should clarify the relationship of responsible leadership and social capital.

\section{Responsible leadership, stakeholder engagement, and social capital}

As I have demonstrated elsewhere (Maak and Pless, 2006a, 2006b), responsible leadership can be defined as the art and ability involved in building, cultivating and sustaining trustful relationships to different stakeholders, both inside and outside the organization, and in co-ordinating responsible action to achieve a meaningful, commonly shared business vision. Arguably, in a stakeholder society an agreeable vision would need to include the aspiration to be(come) an inclusive, responsible, and active business in society; one that aspires to be part of a sustainable future and thus of the solution to and not part of the world's problems. Responsible leadership is about bringing such vision to life by mobilizing stakeholders inside and outside the organization to contribute to business sustainability and legitimacy. As such, it is a relational and ethical phenomenon which occurs in social interaction with those who are affected by or affect the leadership project and thus have a stake in both purpose and vision of the leadership relationship (Freeman et al., 2006; Maak and Pless, 2006b).

As defined above, social capital consists of social structures and resources inherent to relationships and is as such and by definition a relational phenomenon. In fact, it has two distinctive characteristics which distinguish social from "human" or other types of capital: (i) "social capital is owned jointly by the parties to a relationship, with no exclusive ownership rights for individuals" (Nahapiet and Ghoshal, 1998: 256); and (ii), it increases rather than decreases with use (ibid., 258). Relational interaction is therefore a precondition for both the emergence and the quality of social capital. The relational symmetry of resources inherent in social capital is also the main reason why any attempt to "use" social capital in one-dimensional ways is doomed to fail: Leaders cannot just "build and use" social capital and relationships (Balkundi and Kilduff, 2005) for individual or organizational benefit without adequate investment in reciprocity. They may get credit if stakeholder relationships are strong enough for tapping into common resources. However, social capital is just that, commonly shared resources that may be mobilized for mutually beneficial responsible action. It is not theirs to spend alone. I argue against this backdrop, paraphrasing Adler and Kwon (2002: 17), that responsible leadership plays an important role in mobilizing the goodwill that is engendered by the fabric of social (stakeholder) relations and that can be mobilized to facilitate responsible action. Key to our understanding of the role of leadership in building and enabling social capital are therefore content and structure. What is the content of the social resources we are talking about? What do we know about the configuration of social capital? As a next step we shall look at the drivers of social capital: opportunity, motivation, and ability. We then discuss some of the risks and benefits before we conclude our initial analysis by looking at possible outcomes, that is the actual value inherent to social capital and the role the responsible leader may have as a "weaver of value networks."

\section{Content}

As mentioned above, what most authors agree on is that there is potential value to the content of social network ties: the norms and values inherent to those ties, levels of trust, mutual obligations, and the level of recognition; in other words the relational dimension or resources of social capital. Another important dimension is the cognitive one, which is how actors think about their relationship, the language and the stories they share and what is commonly perceived as desirable. "To a considerable extent, organizations and environments exist as cognitions in the minds of leaders and followers." (Balkundi and Kilduff, 2005: 946) Consequently, both dimensions determine the ethical quality of social capital. I will discuss relational aspects first and then turn to the cognitive dimension. 
Our notion of responsible leadership as a socialrelational phenomenon focuses on a wide range of stakeholders as (potential) followers both inside and outside the organization (Maak and Pless, 2006b: 102). While leader and internal stakeholders, notably employees, might share common norms and values and will normally have established a certain level of trust, this is not necessarily true for the relationship of a leader with external stakeholders, at least not those who might have been considered less relevant to running a business in the past like e.g., NGOs or community representatives. In other words, while a business leader might have good relationships to clients, banks, and important shareholders, he might have no relationship or worse, a negative one, with NGOs, shareholder activists, or local politicians. Here we find both the chance and challenge to establish a level of trust and understanding with external stakeholders and ultimately stakeholder social capital. In case of "negative ties" (Brass, 2001) - negative affective judgments toward an organizations' leadership or leader, e.g., from NGOs - the challenge for a leader is to move from confrontation to co-operation and partnership (Austin, 2000). Not until he succeeds can social capital and access to resources develop. The ultimate leadership challenge here is to engage all relevant stakeholders in a coalition for responsible change, thereby creating a social network of stakeholders who are connected through a common purpose: contributing to shaping a business that is obliged to balanced values creation and aspires to be recognized as responsible and sustainable and thus a legitimate part of society. Based on clarified expectations, obligations, mutual commitments, and established trustworthiness social capital - woven and promoted by the leader becomes a resource for responsible action (Coleman, 1988).

Obviously, much of what makes up social capital is engendered by shared norms and values. While these may differ more or less significantly when it comes to professional values - a business leader might value different things in his professional life than an NGO activist - there is common ground in terms of human values; that is, being human, leader, and stakeholders reference the same generalized norms of human interaction. Moreover, it could be argued that the more consciously and explicitly the actors base their action and judgment on ethical principles of "mutual recognition" (Honneth, 1996; Williams, 1997; Maak, 1999; Ricoeur, 2005), the more they adhere to mutual respect, appreciation and understanding, the better are the chances for increase in social capital. Ethically speaking, social capital per se is more than just give and take, more than generalized "norms of reciprocity" (Gouldner, 1960). Otherwise it would not be valuable, or "capital" for that matter. Thus, it is important for a leader to help establish common ethical ground and to nourish a relationship ethic with all stakeholders; a foundation on which social capital will then develop.

This foundation - the shared norms and values, what an organization is and what a responsible business should do (and not do), and the way the relations of a business and its stakeholders is conceived of and structured - exists to a considerable extent as cognitions in the minds of leaders and followers, i.e., stakeholders. In other words, the way an organization conducts its business, how it interacts with stakeholders, which stakeholders it considers relevant and what stakeholders perceive as a responsible business (and business leader), depends considerably on how both business leaders and stakeholders think about it. If they think alike, tapping into common social resources may be easier. If they think differently, some "bridging" needs to be done to align the cognitions. However, as we will see below, the potential benefit of bridging "cognitive holes" may even be greater.

A considerable challenge for a leader here is to deal consciously and responsibly with the "cognitive complexity" (Hooijberg et al., 1997) inherent in the social stakeholder structures of the organization. Moreover, leadership effectiveness will depend on how well this sense-making process functions, both with respect to the challenge of leading responsibly (Maak and Pless, 2006a) and with respect to CSR, or corporate responsibility (Basu and Palazzo, 2008), and thus to the notion of the stakeholder corporation (Post et al., 2002; Wheeler and Sillanpää, 1997).

\section{Structure}

Not only the relations a leader builds and maintains with others, i.e. stakeholders, are important for social capital to emerge, but also the structure of these relations. "Unlike other forms of capital, social 
capital inheres in the structure of relations between actors and among actors." (Coleman, 1988: S98) In fact, the structural dimension of social capital has been researched extensively due to its closeness to research on networks and access to network resources (see e.g., Burt, 1997; Portes, 1998; Uzzi, 1997). Nahapiet and Ghoshal (1998) have summarized the structural facets as network ties, network configuration, and appropriable organization. They argue that "the fundamental proposition of social capital theory is that network ties provide access to resources" (1998: 252); who you know is who you are as the saying goes. Consequently, "bonding" views emphasize symmetrical ties and thus the density of ties as a desirable feature ("warmer, and more social..."), while "bridging" views posit that the specific position of an actor within a network of mostly asymmetrical ties - to different actors or group of actors from different backgrounds with equally diverse networks - might be the most beneficial, as connecting largely loose ties enables tapping into new resources. "Bridging" or configuration views build on Granovetter's work on the "strength of weak ties" (1973) and subsequently on Burt's influential "structural hole theory" (1992, 1997, and 2005). "The structural hole argument defines social capital in terms of the information and control advantages of being the broker in relations between people otherwise disconnected in social structure... The structural hole is an opportunity to broker the flow of information between people and control the form of projects that bring together people from opposite sides of the hole." (Burt, 1997: 340)

In addition, social capital developed in one context might be transferred from one social setting to another - e.g., personal relationships to business exchanges (Burt, 1992) - and may thus provide a valuable resource for different purposes like, for example, stakeholder engagement and dialogue. Nahapiet and Ghoshal (1998: 253) call this "appropriable organization" which may provide access to, and participation in, a larger network of people, or stakeholders, for that matter.

It comes as no surprise then that since leadership action has significant influence on the embeddedness of organizational relations and the network of stakeholder relations respectively enabling relational exchange, building and sustaining trustful stakeholder relationships should be considered a priority for a responsible leader. The leadership void we find in much of social capital research, most notably in “bonding" views, like e.g., Putnam's (1995, 2000), is due to a communitarian, bottom-up tradition; yet, hierarchy too is important because at least indirectly it influences social capital by shaping its enabling social structures (Adler and Kwon, 2002: 27). However, responsible leadership is not a top-down approach; given the complexity of stakeholder relationships hierarchical leader-follower relations like those between management and employees are more the exception than the rule. In most relationships to stakeholders a leader acts on a level playing field. And while a leader has a key role in enabling social capital building, it is important to note that due to the configuration of stakeholder network ties and the fact that in formal terms most stakeholders are of equal status and arguably less dependent than employees (Maak and Pless, 2006a) this role might best be described as that of a broker, enabler, and facilitator.

Against this backdrop centrality might be a more appropriate term than hierarchy as it is strongly related to leadership influence and contingent on the structure of relationships (Brass, 2001). Being central in a network of stakeholders, the responsible leader is instrumental in shaping an organization's relationships to internal and external stakeholders and thus plays the key role in building and managing the interplay of different levels of social capital, in enabling social capital and in maintaining it.

Internally, the leader's task may be twofold. On the one hand, to strengthen the network ties among people and divisions to create bonding social capital and enable enough density or "social glue" to support and nourish a values-conscious corporate culture. On the other hand, to encourage people to strengthen their own network ties to other stakeholders in order to keep the organization synchronized with the many stakeholders around it, to keep it alive and embedded. New societal trends or challenges are likely to emerge at weak ends of network ties rather than at the center of attention. It is therefore important for a responsible leader to keep the organizational network structure afloat that is dynamic and flexible enough.

Externally, as noted above, the leader occupies a central role as broker and facilitator of stakeholder relationships and ultimately as enabler of stakeholder 
social capital. Being embedded in and central to a network of stakeholder relationships a leader is key in engaging stakeholders, in co-opting them to realize a mutually desirable vision and in connecting them for the purpose of responsible change thereby bridging potential structural holes. Leaders who occupy brokerage positions in stakeholder networks ultimately have better access to information (Gargiulo and Benassi, 2000) and therefore know more about opportunities to engage different stakeholders - and their networks - in the pursuit of responsible change.

Yet, given the complexity and diversity of ties it becomes a challenge for the leader to follow the right path and bridge the right holes and not to become trapped in bridging too many indirect ties, conflicting priorities and wasting resources. The structural work in enabling stakeholder social capital is about active relationship work, but not about relational actionism and thus networking as l'art pout l'art. It is therefore important to discriminate "white holes" from "black holes," as Podolny and Baron (1997: 689) put it - the one's who should be bridged from the one's who should be left alone. It might, e.g., be highly beneficial to engage with an NGO like, say, the Rainforest Alliance, a New York based group focusing on engaging multinational companies in socially and environmentally sound practices in Latin America, than an activist group whose main interest is in attacking corporations, not in collaborating with them. Therefore, rather than becoming trapped in endless justification discourses a leader might want to engage his organization on an ongoing basis in stakeholder partnerships where all parties involved act on level playing field and are willing to learn from each other in the pursuit of responsible change. That does not mean that these relationships are free from conflict. On the contrary, dealing with differences and value conflicts is key to learning and change. Yet, as, e.g., the successful collaboration between Chiquita and Rainforest Alliance shows, it takes common goals to turn differences and asymmetrical ties into bridging capital (Taylor and Scharlin, 2004).

A core task of the leader as bridge builder is against this backdrop the actual bridging of cognitive and relational differences to stakeholders to enable a productive collaboration and thus stakeholder social capital. Furthermore, a responsible leader seeks to close structural holes between otherwise unconnected stakeholders; thereby connecting them for the purpose of pursuing higher-level goals such as ethical business practices and sustainable development. In other words, a leader is central in creating a broader stakeholder network of essentially weaker external ties and stronger internal ties. Still, there is "strength of weak ties" (Granovetter, 1973) to external stakeholders if a leader succeeds in enabling access to new resources in order to build and sustain a truly responsible business. However, "strength" of ties does not necessarily imply density - it might for selective internal ties; above all it is the quality of stakeholder relationships that counts. The leader's central task is to create and engage in structures that enable the access to these resources inherent in the nodes and relations of a stakeholder network.

\section{Opportunity, motivation, and ability}

Obviously, this bridging creates the opportunity for better understanding, trust building, co-operation and ultimately enabling of stakeholder social capital. However, tieing into these resources and "mobilizing invisible assets" (Itami, 1991) requires an adequate account of who counts and with whom to engage. In other words it should start with a thorough analysis of the stakeholder network: to whom exist either weak or strong ties? Are any stakeholders missing? Are network and structure characterized by openness or closeness, and might a shift from one to the other be required? Is there enough frequency and flexibility in stakeholder relationships? Do dominant stakeholders (e.g., shareholders) 'suffocate' dependent or emerging ones and thus hinder stakeholder social capital from emerging? What needs to be done to assure the quality of stakeholder relationships to all relevant ones - dominant, dependent, distant, or dormant (Mitchell et al., 1997) - and where and how are structural holes (Burt) that need to, or should be, bridged, e.g., to tie into resources of otherwise unconnected stakeholders?

Thus, enabling opportunities requires a sound approach to stakeholder salience as "the principle of who and what really counts" (Mitchell et al., 1997), or should count, given the challenge of building and sustaining a legitimate business. Due to her centrality in the network of stakeholder relations the leader's 
role is that of being a network architect, a weaver and broker of stakeholder relationships. This role is not easy and the mapping of a network alone, as Adler and Kwon (2002) have argued, is a challenging task given the complexity, diversity, and configurational differences in relationships. Yet, the many potential benefits of tapping into previously inaccessible social resources seem well worth the struggle.

To succeed and master the challenge of building sustainable relationships to stakeholders that are rich in social capital a leader must make sure that it is done for the right reasons. For social capital to emerge a certain level of trust and sociability needs to be established. This is only possible if stakeholders believe that they are not instrumentalized for the purpose of maximizing profits but engaged instead to contribute to balanced values creation. Thus, in contrast to the dominant assumption in social capital research that actors are driven by instrumental reasons in exploiting resources for individual benefit, I argue that stakeholder social capital as sketched above will emerge only if an organization and her leader engenders and communicates a moral motivation based on normative commitment to responsible business practices. Moreover, if stakeholders detect that they are being used for instrumental reasons rather than based on norms of mutual recognition such attempt might even be counterproductive to establishing durable relationships. Obviously, stakeholder social capital and "enforced trust" (Portes, 1998) contradict each other; trust is a delicate resource, it needs to be dealt with accordingly and it can be both a source of social capital and the result of social capital (Adler and Kwon, 2002; Lin, 2001), once stakeholder engagement proves to be mutually fruitful in pursuing the shared goal of contributing to a sustainable future.

Finally, abilities - "the competencies and resources at the nodes of the network" (Adler and Kwon, 2002: 26) - and thus the way how a leader utilizes his stakeholder network and what competencies he needs, has not received any significant attention in research so far. Yet, Adler and Kwon (2002) stress that this ability impacts the outcome and is therefore constitutive for social capital to emerge. It is among the goals of this article to stress the necessity for future research to contribute to enabling responsible leadership in a stakeholder society by clarifying what leadership abilities are needed and how these may be developed in current and future leaders.

\section{Benefits and risks}

Ultimately, social capital is about the value of connections (Borgatti and Foster, 2003) and information. It connects people or groups of people in social networks that generate solidarity, goodwill, and mutual influence; and it not only enables access to information but also improves the information's quality and relevance (Coleman, 1988). Again, the Chiquita-Rainforest Alliance partnership may illustrate these benefits: while the NGO was able to forward its agenda significantly and improve the social and environmental conditions on the company's plantations, Chiquita got access to information and knowledge on how to implement a state of the art sustainability program. Promoted and brokered by both organization's leadership, the alliance generated significant goodwill on both sides, higher levels of trust, and even solidarity in moving the sustainability agenda forward to achieve mutually desirable goals.

Thus, from a company perspective the obvious benefits of stakeholder social capital are increased stakeholder goodwill vis-à-vis the organization (Adler and Kwon, 2002), higher levels of trust, and ultimately a reputation as a concerned, responsible, caring, and thus authentic organization. By co-opting stakeholders, by eliminating negative ties and building coalitions for positive change, by aligning mutual expectations and by moving from confrontation to partnership - and thus by strengthening the ties to all relevant stakeholders, responsible leadership furthers the embeddedness of an organization as a responsible and trustworthy business in society. Moreover, as Maurer and Ebers (2006) have recently shown, organizations can appropriate at the same time both the benefits of strong, cohesive ties with selected partners "and the opportunities provided by a wider range of ties with different constituencies at the firm level" (286). In fact, to fully leverage the benefits of social capital and not being trapped in social inertia organizational adaptability is crucial. Maurer and Ebers (2006) show in their study on biotechnology start-ups that the most successful firms were those who balanced selected strong ties with a wider range of weaker, external ties and thereby social capital and 
a high level of organizational adaptability. I argue against this background that responsible leadership in a stakeholder society needs to tap in the strength of weak stakeholder ties while it should avoid the weakness of strong ties, that is, it needs to balance sociability and adaptability of the organization. Again, while it can be argued that high levels of social capital are desirable in terms of trust and understanding (and better stakeholder relationships) it is not the level of density but the quality of these relationships which is important. A leader's task is to make sure that the stakeholder network consists of balanced social capital and that overembeddedness in particular relationships is avoided. Overembeddedness, e.g., in the (cognitive) relationship to shareholders, reduces the flow of information, shifts the level of attention and can lead to inertia (Gargiulo and Bernassi, 2000).

The possible "cognitive lock-in" (Uzzi, 1997) of an organization can be highly problematic, as e.g. the well-documented case of Shell "Brent Spar" illustrates: caught in a technological mindset the cognitive lock-in misled Shell's leadership by ignoring wider environmental concerns and stakeholder protests. At the time, the Shell management thought it had done everything right, even from a moral point of view, and just could not understand why people were protesting the intended sinking of the oilrig in the North Sea. Initially, they simply blamed Greenpeace for misleading the public. However, a balanced stakeholder network - which the company now has - would have led them to a different approach.

Thus, while investing in strong ties to a selected groups of key stakeholders may increase the level of social capital for an organization it is advisable for a leader to also cultivate weaker ties as well as new ties and bridge structural holes in the stakeholder network of the organization to generate non-redundant information, leverage the potential benefits of both the complexity and multiplexity of stakeholder relationships and ultimately new forms of social capital. The emerging stakeholder social capital increases the efficiency of action (Nahapiet and Ghoshal, 1998) and reduces transaction costs due to better understanding and higher levels of trust.

The benefits of stakeholder social capital are, e.g., illustrated by a partnership between the outdoor apparel maker Timberland and "City Year," a NGO who does inner-city youth work. After years of successful collaboration on different projects the
NGO even moved into Timberland's headquarters and now serves as a steady reminder of Timberland's embeddedness in society and commitment to social and environmental progress. It almost functions as a corporate responsibility think tank, with leaders of both organizations closely interacting. (Maak and Ulrich, 2007) The partnership generated high levels of trust and solidarity (and arguably a competitive advantage for Timberland), as both care about the same goals and share the vision of a sustainable future, all of which also contribute to the common good.

It should be noted that among the risks associated with social capital are not only inertia and low adaptability, but also exclusion, excess claims on partners and restrictions on the freedom to act (Portes, 1998). While these risks apply to close group relations and bonding social capital they are arguably less relevant for diverse stakeholder relations. Among the key challenges there, as mentioned above, is to deal with the complexity of norms and values inherent to the relationships to multiple stakeholders - and therefore not "network closure" (Coleman, 1988), but network complexity. In addition, a leader should be aware of the relational work involved as well as rising expectations from stakeholders with respect to mutual engagement and relations. In sum, however, the many benefits of enabling and facilitating stakeholder engagement to generate social capital clearly outweigh the risks.

We started our analysis of the role of leadership in building and enabling social capital by discussing content and structure. As a next step we looked at the drivers of social capital: opportunity, motivation, and ability. We then discussed some of the risks and benefits. Before we conclude our analysis by looking at the actual value inherent to social capital and the role of the responsible leader as a "weaver of value networks" Figure 1 integrates the various elements, drawing on both Adler and Kwon (2002), and Nahapiet and Ghoshal (1998), and illustrates the role of responsible leadership with respect to stakeholder engagement and social capital.

\section{Conclusion: The responsible leader as weaver of value networks}

Balkundi and Kilduff (2005: 956) argue that leadership "requires the management of social relationships. Starting with the cognitions in the mind of the leader 


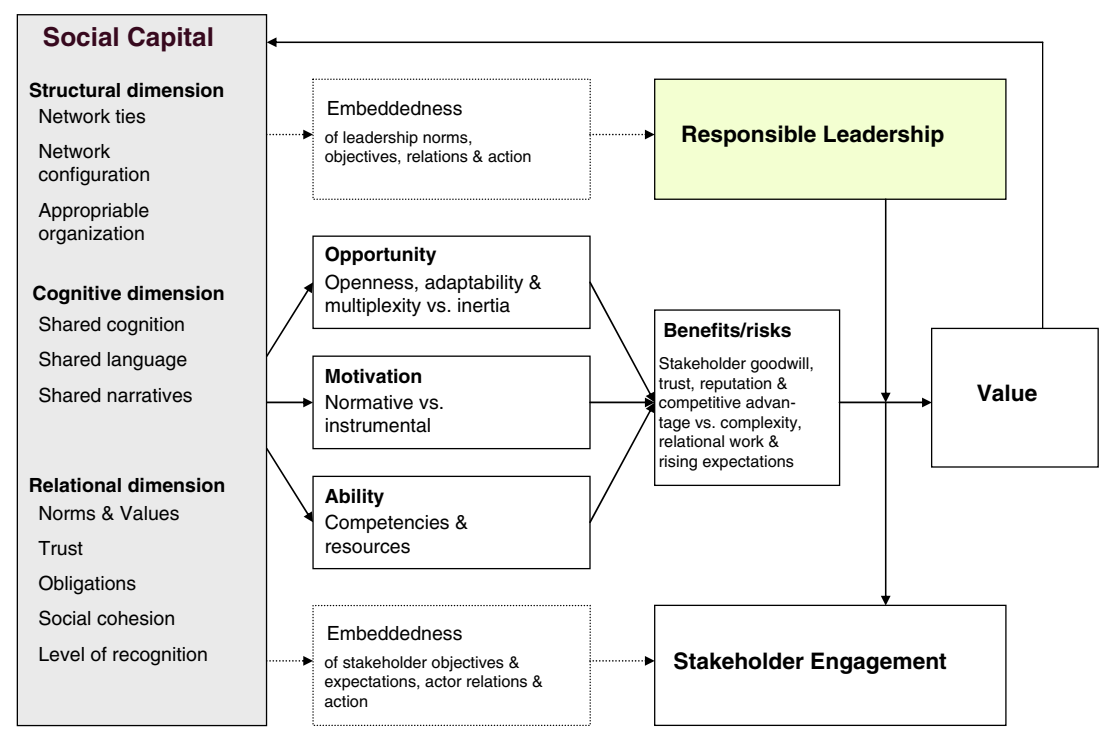

Figure 1. Responsible leadership, stakeholder engagement and social capital.

concerning the patterns of relationships in the ego network, the organizational network, and the interorganizational network, social ties are formed and maintained, initiatives are launched or avoided, and through these actions and interactions, the work of the leader is accomplished." I suggested in this article that leaders ought to pay attention to a particularly important part of this work, namely the potential benefits of generating social capital by building and sustaining trustful relationships to all relevant stakeholders of an organization in order to achieve responsible change. Stakeholders expect from corporate leaders that they make sure that their organizations contribute to a sustainable future and are thus part of the solution to some of the world's most pressing problems, and are not considered part of the problems.

Accordingly, responsible leadership, as "transforming leadership" (Burns, 1978), depends on the mutual pursuit of business leaders and stakeholders alike to achieve higher-level goals based on a shared vision of the role of business in society. Due to the centrality of leaders in the network of stakeholder relations they are key to both the pursuit of responsible change and the enabling of stakeholder social capital. Responsible leaders create stable relationships with trusted partners, over time these ties accumulate into a mutually beneficial network
(Balkundi and Kilduff, 2005) and ultimately generate stakeholder social capital. Given the diversity of network partners and expectations, managing and leading in such a network requires a versatile leader with social and ethical intelligence. Obviously, this is not the "big ego"-type of leader that we still find in much of the leadership literature, but has to be a much more humble networker and mediator who engages herself among equals. (Maak and Pless, 2006b) Therefore, as argued above, the responsible leader acts as a weaver of stakeholder relationships and as broker of social capital in the pursuit of responsible change.

Interestingly enough, Plato saw this quite clearly in his "Statesman," where he noted that people are not sheep, and leaders are not shepherds; Plato regarded the leader as a weaver, whose main task was to weave together different kinds of people into the fabric of society. (Plato, 1971; cit. in Ciulla, 2004: 322) To conclude, I suggest to think of a responsible leader with respect to stakeholder engagement as a weaver of social ties, as an embedded and engaged networker who makes sure that her organization is 'in sync' with stakeholder expectations, and who is able to mobilize multiple stakeholders in a coalition to build a responsible and sustainable business. Consequently, responsible leadership may result in the creation of value networks (Lord and Brown, 
2001: 141) of multiple stakeholders, which enhance social capital and thereby contribute to both a sustainable business and the common good.

\section{References}

Adler, P. S. and S. W. Kwon: 2002, 'Social Capital: Prospects for a New Concept', Academy of Management Review 27(1), 17-40.

Andriof, J. and S. Waddock: 2002, 'Unfolding Stakeholder Engagement', In J. Andriof, S. Waddock, B. Husted and R. S. Sutherland (eds.), Unfolding Stakeholder Thinking: Theory, Responsibility and Engagement (Greenleaf Publishing, Sheffield), pp. 19-42.

Apel, K.-O.: 1988, Diskurs und Verantwortung (Suhrkamp, Frankfurt am Main).

Austin, J. E.: 2000, The Collaboration Challenge (JosseyBass, San Francisco).

Balkundi, P. and M. Kilduff: 2005, 'The Ties That Lead: A Social Network Approach to Leadership', The Leadership Quarterly 16, 941-961.

Ballet, J.: 2005, 'Stakeholders et Capital Social', Revue Francaise de Gestion 156(3), 77-91.

Basu K., and G. Palazzo: 2008, 'Corporate Social Responsibility. A Process Model of Sensemaking', Academy of Management Review (forthcoming).

Benioff, M. and K. Southwick: 2004, Compassionate Capitalism: How Corporations Can Make Doing Good an Integral Part of Doing Well (Career Press, Franklin Lakes, NJ).

Borgatti, S. P. and P. Foster: 2003, 'The Network Paradigm in Organizational Research: A Review and Typology', Journal of Management 29, 991-1013.

Bourdieu, P.: 1980, 'Le Capital Social: Notes Provisoires', Actes de la Recherche en Sciences Sociales 31, 2-3.

Bourdieu, P.: 1985, 'The Forms of Capital', In J. G. Richardson (ed.), Handbook of Theory and Research for the Sociology of Education (Greenwood, New York).

Bourdieu, P. and L. J. D. Wacquant: 1992, An Invitation to Reflexive Sociology (Universiy of Chicago Press, Chicago).

Boaytzis, R. and A. McKee: 2005, Resonant Leadership (Harvard Business School Press, Boston, MA).

Brass, D. J.: 2001, 'Social Capital and Organizational Leadership', In S. J. Zacarro and R. Klimoski (eds.), The Nature of Organizational Leadership, SIOP Frontiers Series (Josey-Bass, San Francisco), pp. 132-152.

Brass, D. J., K. D. Butterfield and B. C. Skraggs: 1998, 'Relationships and Unethical Behavior: A Social Network Perspective', Academy of Management Review 23(1), 14-31.

Burke, E. M.: 2005, Managing a Company in an Activist World: The Leadership Challenge of Corporate Citizenship (Praeger, Westport, CT/London).
Burt, R. S.: 1992, Structural Holes. The Social Structure of Competition (Harvard University Press, Cambridge, MA).

Burt, R. S.: 1997, 'The Contingent Value of Social Capital', Administrative Science Quarterly 42, 339-364.

Burt, R. S.: 2005, Brokerage and Closure: An Introduction to Social Capital (Cambridge University Press, Cambridge).

Carroll, G. R. and A. C. Teo: 1996, 'On the Social Networks of Managers', Academy of Management Journal 39(2), 421-440.

Burns, J. M.: 1978, Leadership (Perennial, New York).

Ciulla, J. (ed.): 1998, Ethics, The Heart of Leadership (Praeger, Westport, CT, London).

Ciulla, J.: 2004, 'Ethics and Leadership Effectiveness', In J. Antonakis, A. T. Cianciolo and R. J. Sternberg (eds.), The Nature of Leadership (Sage, Thousand Oaks/London/New Dehli), pp. 302-327.

Ciulla, J.: 2006, 'Ethics. The Heart of Leadership', In Th. Maak and N. M. Pless (eds.), Responsible Leadership (Routledge, London/New York).

Cohen, D. and L. Prusak: 2001, In Good Company: How Social Capital Makes Organizations Work (Harvard Business School Press, Boston, MA).

Coleman, J. S.: 1988, 'Social Capital in the Creation of Human Capital', The American Journal of Sociology 94, S95-S120.

DeGeorge, R. T.: 1993, Competing with Integrity in International Business (Oxford University Press, Oxford/ New York).

Doh, J. P. and S. A. Stumpf (eds.): 2005, Handbook on Responsible Leadership and Governance in Global Business (Edward Elgar, Cheltenham/Northampton, MA).

Donaldson, T.: 1996, 'Values in Tension: Ethics Away from Home', Harvard Business Review 74(5), 48-56.

Donaldson, T. and L. E. Preston: 1995, “The Stakeholder Theory of the Corporation: Concepts,' Evidence, and Implications', Academy of Management Review 20(1), 65-91.

Elkington, J.: 1998, Cannibals with Forks: The Triple Bottom Line of 21st Century Business (New Society Publishers, Gabriola Island, BC/Stony Creek, CT).

Freeman, R. E.: 1984, Strategic Management: A Stakeholder Approach (Pitman Publishers, Boston).

Freeman, R. E.: 1994, 'The Politics of Stakeholder Theory: Some Future Directions', Business Ethics Quarterly 4(4), 409-422.

Freeman, R. E.: 2004, 'Ethical Leadership and Creating Value for Stakeholders', In R. A. Peterson and O. C. Ferrell (eds.), Business Ethics (M.E. Sharpe, Armonk, NY, London).

Freeman, R. E., K. Martin, B. Parmar, M. P. Cording and P. H. Werhane: 2006, 'Leading Through Values and Ethical Principles', In R. Burke and C. Cooper (eds.), Inspiring Leaders (Routledge, London, New York). 
Galaskiewicz, J. and D. Shatin: 1981, 'Leadership and Networking among Neighborhood Human Service Organizations', Administrative Science Quarterly 26, 434-448.

Gargiulo, M. and M. Benassi: 2000, 'Trapped in Your Own Net? Network Cohesion, Structural Holes, and the Adaption of Social Capital', Organization Science 11(2), 183-196.

Gittell, R. and A. Vidal: 1998, Community Organizing: Building Social Capital as a Development Strategy (Sage Publ, Newbury Park, CA).

Gouldner, A.: 1960, 'The Norm of Reciprocity: A Preliminary Statement', American Sociological Review 25, 161-178.

Granovetter, M.: 1973, 'The Strength of Weak Ties', American Journal of Sociology 78(6), 1360-1380.

Granovetter, M.: 1985, 'Economic Action, Social Structure, and Embeddedness', American Journal of Sociology 91, 481-510.

Habermas J.: 1981, Theorie des kommunikativen Handelns, Vol. 1: Handlungsrationalität und gesellschaftliche Rationalisierung. Suhrkamp, Frankfurt am Main.

Habermas, J.: 1991, Erläuterungen zur Diskursethik (Suhrkamp, Frankfurt am Main).

Hanifan, L.: 1916, 'The Rural School Community Center', Annals of the American Academy of Political and Social Science 67, 130-138.

Hart, S. L.: 2005, Capitalism at the Crossroads (Wharton School Publishing, Upper Saddle River, NJ).

Hirsch, P. M. and D. Z. Levin: 1999, 'Umbrella Advocates versus Validity Police: A Life-Cycle Model', Organization Science 10, 199-212.

Hitt, M. A. and R. D. Ireland: 2002, 'The Essence of Strategic Leadership: Managing Human and Social Capital', The Journal of Leadership and Organizational Studies 9(1), 3-14.

Honneth, A.: 1996, The Struggle for Recognition: The Moral Grammar of Social Conflicts (MIT Press, Cambridge, MA).

Hooijberg, R., J. G. Hunt and G. E. Dodge: 1997, 'Leadership Complexity and Development of the Leaderplex Model', Journal of Management 23, 375-408.

Ibarra, H., M. Kilduff and W. Tsai: 2005, 'Zooming In and Out: Connecting Individuals and Collectivities at the Frontiers of Organizational Network Research', Organization Science 16(4), 359-371.

Itami, H.: 1991, Mobilizing Invisible Assets (Harvard University Press, Cambridge, MA).

Jacobs, J.: 1965, The Death and Life of Great American Cities (Penguin, London).

Jones T. M., W. Felps and G. Bigley: 2007, 'Ethical Theory and Stakeholder-Related Decisions: The Role of Stakeholder Culture', Academy of Management Review 32(1), 137-155.
Kellerman, B.: 2004, Bad Leadership: What it is, How it Happens, Why it Matters (Harvard Business School Press, Boston, MA).

Lin, N.: 2001, Social Capital: A Theory of Social Structure and Action (Cambridge University Press, Cambridge).

Lord, R. G. and D. J. Brown: 2001, 'Leadership, Values, and Subordinate Self-Concepts', The Leadership Quarterly 12, 133-152.

Loury, G. C.: 1977, 'A Dynamic Theory of Racial Income Differences', In P. A. Wallace and A. M. LaMonde (eds.), Women, Minorities, and Employment Discrimination (Lexington Books, Lexington, MA), pp. 153-186.

Maak, Th.: 1999, Die Wirtschaft der Bürgergesellschaft (Haupt, Bern/Stuttgart/Vienna).

Maak, Th. and N. M. Pless (eds.): 2006, Responsible Leadership (Routledge, London/New York).

Maak, Th. and N. M. Pless: 2006a, 'Responsible Leadership: A Relational Approach', In Th. Mak and N. M. Pless (eds.), Responsible Leadership (Routledge, London, New York).

Maak, Th. and N. M. Pless: 2006b, 'Responsible Leadership in a Stakeholder Society', Journal of Business Ethics 66, 99-115.

Maak, Th. and P. Ulrich: 2007, Integre Unternehmensführrung. Ethisches Orientierungswissen für die Wirtschaftspraxis (Schäffer-Poeschel, Stuttgart).

Maurer, I. and M. Ebers: 2006, 'Dynamics of Social Capital and Their Performance Implications: Lessons from Biothechnology Start-Ups', Adminstrative Science Quarterly 51, 262-292.

Mitchell, R. K., B. R. Agle and D. J. Wood: 1997, 'Toward a Theory of Stakeholder Identification and Salience: Defining the Principle of Who and What Really Counts', Academy of Management Review 22(4), 853-886.

Moorthy, R. S., R. T. DeGeorge and T. Donaldson, et al.: 1998, Uncompromising Integrity: Motorola's Global Challenge (Motorola University Press, Schaumburg, IL).

Nahapiet, J. and S. Ghoshal: 1998, 'Social Capital, Intellectual Capital, and the Organizational Advantage', Academy of Management Review 23(2), 242-266.

Nooteboom, B.: 2002, Trust: Forms, Foundations, Functions, Failures and Figures (Edward Elgar Publ, Cheltenham/Northampton, MA).

Pless, N. M. and Th. Maak: 2005, 'Relational Intelligence for Leading Responsibly in a Connected World', In K. M. Weaver (ed.), Proccedings of the 65th Annual Meeting of the Academy of Management (Honolulu, HI).

Podolny, J. M. and J. N. Baron: 1997, 'Resources and Relationships: Social Networks and Mobility in the Workplace', American Sociological Review 62, 673-693.

Portes, A.: 1998, 'Social Capital: Its Origins and Application in Modern Sociology', Annual Review of Sociology 24, 1-24. 
Post, J. E., L. E. Preston and S. Sachs: 2002, Redefining the Corporation: Stakeholder Management and Organizational Wealth (Stanford University Press, Stanford, CA).

Prahalad, C. K.: 2005, The Fortune at the Bottom of the Pyramid: Eradicating Poverty through Profits (Wharton School Publishing, Upper Saddle River, NJ).

Price, T. L.: 2005, Understanding Ethical Failures in Leadership (Cambridge University Press, New York).

Putnam, R. D.: 1993, Making Democracy Work (Princeton University Press, Princeton).

Putnam, R. D.: 1995, 'Bowling Alone: America's Declining Social Capital', Journal of Democracy 6, 65-78.

Putnam, R. D.: 2000, Bowling Alone: The Collapse and Revival of American Community (Simon \& Schuster, New York).

Ricoeur, P.: 2005, The Course of Recognition (Harvard University Press, Cambridge, MA).

Ring, P. S. and A. H. Van de Ven: 1994, 'Developmental Processes of Cooperative Interorganizational Relationships', Academy of Management Review 19, 90-118.

Svendsen, A.: 1998, The Stakeholder Strategy (BerrettKoehler, San Francisco).

Taylor, J. G. and P. J. Scharlin: 2004, Smart Alliance: How a Global Corporation and Environmental Activists Transformed a Tarnished Brand (Yale University Press, New Haven and London).

Uzzi, B.: 1997, 'Social Structure and Embeddedness', Administrative Science Quarterly 42, 35-67.
Walker, G., B. Kogut and W. Shan: 1997, 'Social Capital, Strutural Holes and the Formation of an Industry Network', Organization Science 8(2), 109-125.

Wheeler, S. and M. Sillanpää: 1997, The Stakeholder Corporation (Pitman Publishing, London etc).

Williams, R. R.: 1997, Hegel's Ethics of Recognition (University of California Press, Berkeley, CA).

Woolcock, M.: 1998, 'Social Capital and Economic Development: Toward a Theoretical Synthesis and Policy Framework', Theory and Society 27, 151-208.

Woolcock, M. and D. Narayan: 2000, 'Social Capital: Implications for Development Theory, Research, and Policy', The World Bank Research Observer 15(2), 225-249.

Young, S.: 2003, Moral Capitalism: Reconciling Private Interest with the Public Good (Berrett-Koehler, San Francisco, CA).

Institute for Business Ethics, University of St. Gallen, Guisanstrasse 11, CH-9010, St. Gallen, Switzerland E-mail:thomas.maak@unisg.ch

INSEAD, Boulevard de Constance, Fontainebleau, Cedex, 77305, France 